Article

\title{
Who Undermines the Welfare State? Austerity-Dogmatism and the U-Turn in Swedish Asylum Policy
}

\author{
Simone Scarpa * and Carl-Ulrik Schierup \\ REMESO-Institute for Research on Migration, Ethnicity and Society, Linköping University, 58183 Linköping, Sweden; \\ E-Mails: simone.scarpa@liu.se (S.C.), carl-ulrik.schierup@liu.se (C.-U.S.) \\ * Corresponding author
}

Submitted: 24 November 2017 | Accepted: 12 February 2018 | Published: 29 March 2018

\begin{abstract}
Within the EU, the so-called "refugee crisis" has been predominantly dealt with as an ill-timed and untenable financial burden. Since the 2007-08 financial crisis, the overarching objective of policy initiatives by EU-governments has been to keep public expenditure firmly under control. Thus, Sweden's decision to grant permanent residence to all Syrians seeking asylum in 2013 seemed to represent a paradigmatic exception, pointing to the possibility of combining a humanitarian approach in the "Iong summer of migration" with generous welfare provisions. At the end of 2015, however, Sweden reversed its asylum policy, reducing its intake of refugees to the EU-mandated minimum. The main political parties embraced the mainstream view that an open-door refugee policy is not only detrimental to the welfare state, but could possibly trigger a "system breakdown". In this article, we challenge this widely accepted narrative by arguing that the sustainability of the Swedish welfare state has not been undermined by refugee migration but rather by the Swedish government's unbending adherence to austerity politics. Austerity politics have weakened the Swedish welfare state's socially integrative functions and prevented the implementation of a more ambitious growth agenda, harvesting a potentially dynamic interplay of expansionary economic policies and a humanitarian asylum policy.
\end{abstract}

\section{Keywords}

asylum policy; austerity; crisis; refugee; Sweden; welfare state

\section{Issue}

This article is part of the issue "The Transformative Forces of Migration: Refugees and the Re-Configuration of Migration Societies", edited by Ulrike Hamann and Gökçe Yurdakul (Humboldt University of Berlin, Germany).

(C) 2018 by the authors; licensee Cogitatio (Lisbon, Portugal). This article is licensed under a Creative Commons Attribution 4.0 International License (CC BY).

\section{Introduction}

Sweden experienced an immediate drop in GDP growth during 2008 and 2009 in the aftermath of the global financial crisis, but fully recovered from the downturn more quickly than other EU countries without endangering public finances as well as managing to keep the government debt-to-GDP ratio at a comparatively low level of about 40 percent (Erixon, 2015; Stenfors, 2016). The Swedish government's handling of the crisis was unanimously praised by international financial institutions and the country came to be held up as some sort of role model for the other EU member-states. Due to its favourable economic and financial situation, together with its strong tradition of refugee protection dating as far back as the early-1970s, Sweden conveyed the impression of being the best-equipped EU country to cope with the "long summer of migration" in 2015 (Kasparek \& Speer, 2015); a period that came to be known by the Euro-centric label "the refugee crisis".

By September 2013, Sweden had become the first country in the world to offer permanent residency to all Syrians seeking asylum. One year after, in August 2014, Fredrik Reinfeldt, the centre-right former prime minister, called on Swedes to "open...[their] hearts to people fleeing under great stress" (Rosén, 2014). In the 
same speech, however, Reinfeldt presaged that the unprecedented humanitarian effort could pose a major challenge for the financial sustainability of the welfare state. Therefore, he appealed to the population to accept, "patiently", the increase in social expenditure resulting from the expected rise in refugee migration, alluding to the need for compensatory spending cuts in other policy areas.

In October 2015, in the context of a heated political debate on Europe and Sweden's so-called "refugee problem" and one year after Reinfeldt's speech, the social democratic Foreign Minister Margot Wallström, representing the newly elected red-green government, made the argument for a sudden but inevitable U-turn in asylum policy in a widely discussed interview with Sweden's leading newspaper (Stenberg, 2015). Wallström imparted that refugee migration had reached an unsustainable level that was threatening to cause the "breakdown" of the "system". Thereafter, "system breakdown" (systemkollaps in Swedish) came to be adopted as a trope across the political spectrum, from the left to the right, as well as in media debates, with 245 instances of this phrase appearing in as many Swedish newspaper articles in November 2015, just a month after the interview (source: Retriever Mediearkivet).

It was precisely that month that the announced U-turn in asylum policy was implemented by the government led by the Social Democratic Prime Minister Stefan Löfven. Refugee admissions were abruptly halted and the maximum rate of refugee acceptance was reduced to the EU-imposed minimum quota. Document checks were introduced at the border with Denmark for the first time since the 1950s, while criminal sanctions against smugglers (including activists moved by humanitarian intentions) were toughened. Since 20 July 2016, permanent residence permits for refugees who were not relocated to Sweden within the EU's refugee quota system were replaced with temporary residence permits, and access to family reunification for recognised refugees was drastically limited. Therefore, the only way for non-relocated refugees to change their status from temporary to permanent became that of obtaining financial self-sufficiency through employment-related income. The aim of this repressive package of regulations was to make Sweden a less attractive destination for asylum seekers and refugees. In this respect, the restrictions proved to be effective as the number of asylum seekers declined drastically from a peak of 156,460 in 2015 (equivalent to the largest per capita number of applications in any EU country) to 22,410 in 2016 (OECD, 2017). The new legislation was presented as temporary in nature and motivated by the exceptional circumstances of the so-called "European refugee crisis". In fact, the aforementioned restrictions are planned to remain in force for a three-year period until July 2019.

The policy U-turn marked a dramatic change in international and domestic perceptions of Sweden as a welcoming country for asylum seekers and refugees. The re- alignment of Swedish asylum policy with that of the rest of the EU mirrored the consolidation of a cross-party consensus around the view of refugee migration as a potential threat for the Swedish welfare state, even in in the context of the fast economic growth that the country experienced after the 2007-08 global downturn (Erixon, 2015). Indeed, the risk of a trade-off between refugee reception and the welfare state's sustainability was first evoked by Reinfeldt's "open-your-hearts" speech, but soon became deployed as an argument for justifying the radical shift in asylum policy implemented by the redgreen government.

The aim of this article is to offer an alternative narrative of the crisis of Sweden's historically unique combination of universalistic social policy and inclusionary multiculturalism, which has been also labelled a "Swedish exceptionalism" (Schierup \& Ålund, 2011). For several decades, the Swedish model's crisis had been repeatedly heralded as an imminent threat in both academic literature and domestic politics. Since the early 1990s, the Swedish welfare state has undergone important transformations involving a stricter conditionality of access to, and decreased generosity of, social security provisions (Palme, Ferrarini, Sjöberg, \& Nelson, 2012) together with deregulation, privatisation and marketisation of nearly all public services (Hartman, 2011; Svallfors \& Tyllström, 2018). Furthermore, despite the comparatively low level of income inequality, Sweden is the OECD country in which inequality has grown the fastest in percentage points since the mid-1980s (OECD, 2011). Yet, the hegemonic rhetoric of an impending "system breakdown" succeeded in obliterating over two decades of self-inflicted neoliberal restructuring and, at the same time, in shifting the blame onto, and therefore scapegoating, refugees for allegedly threatening to plunge the vestiges of the Swedish model into a crisis.

We argue for a reversal of this causality. Our argument is that that the sustainability of the Swedish model has not been undermined by recent refugee migration but rather by the Swedish government's dogmatic adherence to austerity politics. Austerity politics have weakened the Swedish welfare state's socially integrative functions and prevented the implementation of a more ambitious growth agenda, harvesting a potentially dynamic interplay of expansionary economic policies and a humanitarian asylum policy.

In the following, we set out to address the relationship between immigration and the welfare state, with a specific focus on the recent Swedish debate surrounding the impact of refugee reception on public finances. Our discussion is narrowed to the economic aspects of refugee migration because this issue has had a major influence on the debate preceding the reform of asylum policy in Sweden. Financial considerations have been some of the underlying reasons for the reorientation of Swedish asylum policy. However, this fact is rarely discussed in the literature, which mainly focuses on the Swedish government's anxiety over the growing xeno- 
phobic and welfare-chauvinistic sentiments in the population (e.g., Dahlstedt \& Neergaard, 2016; Demker \& Van der Meiden, 2016; Norocel, 2016; Rydgren \& Van der Meiden, 2016). Thereafter, we go on to analyse policy developments in Sweden from the early-1990s onwards by explaining how austerity politics steadily weakened the effectiveness of the Swedish state-centred approach to refugee integration. Our argument is that the conditions for a "system breakdown" were not created by the increase of refugee migration but rather by the Swedish government's unbending adherence to austerity politics. In the conclusions, we discuss possible future developments of what remains of the Swedish model in the context of the upcoming national elections scheduled for September 2018.

\section{Refugee Migration: Fiscal Cost or Dividend?}

The hypothesis that international migration may have a potentially detrimental effect on the welfare state of receiving countries has gained substantial influence in research, particularly since the publication of a widely cited study by Alesina and Glaeser (2004). These scholars contended that roughly half of the differences in welfare state spending between European countries and the US could be explained by the decline in collective solidarity associated with the ethno-racial "fractionalisation" of the US population; i.e. its segmentation into groups differing in terms of language, religion or other cultural markers. Alesina and Glaeser projected that European countries would experience an analogous crisis of solidarity as a response to increased international immigration. They argued that immigration-induced diversity would pave the way for the downsizing of European welfare states.

The hypothesis that diversity has a negative effect on the development of welfare states has been questioned primarily on historical grounds due to the differences between the ethno-racial history of the US and the more recent immigration history of European countries (Kymlicka \& Banting, 2006). Another counter-argument points to the institutional and political differences between the US and European countries. For example, Mau and Burkhardt (2009) demonstrated that ethnic diversity does not necessarily translate into distributive conflicts between groups if welfare states are institutionally designed to prevent the emergence of such conflicts. An additional factor to be taken into consideration is the political context of reception countries. Hence, Taylor-Gooby (2005) replicated the statistical analysis conducted by Alesina and Glaeser, but adding a variable considering the relative strength of the left parties in each country. He found that this was the variable with the strongest positive effect on welfare spending and that, when included in the original statistical model, the negative effect of ethno-racial fractionalisation on welfare spending lost its statistical significance. Therefore, he concluded that "the presence of the left appears to be able to insu- late welfare systems against the impact of greater diversity among citizens" (Taylor-Gooby, 2005, p. 671).

The Swedish model has long been seen as a case in point for the capacity of left political institutions to counteract the expected negative impact of greater ethnic diversity on the welfare state. The Swedish model's unique combination of strongly redistributive social policies and a very liberal asylum policy has epitomised the power of social-democratically inspired politics to hinder the potentially fractionalising effects of large-scale immigration. In effect, the Swedish approach to refugee integration and multiculturalism has been described as state-centred; i.e., entailing a strong reliance on the politically integrative functions of universalistic welfare institutions, encompassing the whole population and transcending ethno-racial divisions (Borevi, 2017).

A more controversial issue is whether the Swedish model has been able to yield gains from the public expenditure invested in promoting refugees' integration into the labour market or, conversely, whether refugees represent a mere burden for the welfare state. Two recent studies based on Swedish register-data sought to estimate the so-called "fiscal cost" of refugee reception in the short- and long-term. The fiscal cost of refugee reception is defined in these studies as the difference between the sum of the taxes and fees paid by refugees, and the total costs of the transfers and services they receive from the welfare state. Joakim Ruist (2015) showed that refugees in Sweden are more likely than natives to be economically dependent on income redistribution policies. He estimated the fiscal cost of refugee migration at one percent of the Swedish GDP in 2007. This, he argues, stems partly from refugees' overrepresentation among welfare beneficiaries, but also from their lower tax contributions associated with lower employment earnings. A study by Lina Aldén and Mats Hammarstedt (2016) focused on the cohorts of refugees who fled to Sweden between 2005 and 2007, following them longitudinally until 2012. The results from their analyses showed that the average refugee had a fiscal cost of about 200,000 Swedish kronor (about $€ 20,000$ ) in the first year after immigration. This cost was cut in half after seven years of domicile in Sweden. Assuming a continuation of this trend, it would take 14 years before refugee migration reaches the breakeven point; i.e., becomes a net gain for public finances. Both studies indicate that although refugee migration is far from putting the financial sustainability of the Swedish welfare state at risk, it represents a substantial and prolonged burden. Yet, despite the increasing academic and political popularity of these analyses, the issue of the economic impact of refugee migration on Swedish society is far from settled in the literature.

In a recent article, political scientist Bo Rothstein (2017) observed that in 2016 the Swedish economy grew four times faster (in terms of GDP growth) than in other Nordic countries. He contended that the previous year's large inflow of refugees was a key driver behind this 
growth. Specifically, the exceptional rate of economic growth was fuelled by what he labelled as "involuntary Keynesianism", namely the fiscal stimulus effect associated with the increase in public expenditure in the Swedish public sector, and in local governments in particular, to sustain the public services needed to manage the large-scale intake of refugees. It is a condition which has also been dubbed "refugee Keynesianism" in the recent Swedish and European debate (Hansen, 2017a).

The view that the high degree of immigration may have a positive effect on the Swedish economy seems to be confirmed by the work of Swedish economist Lennart Erixon (2015). Erixon estimated that the increased labour supply through refugee migration has contributed considerably to the high GDP growth in Sweden in the aftermath of the 2007-08 crisis. At the same time, refugee migration has resulted in a decrease in the share of the working-age population for the total population. For this reason, Swedish economic performance was less positive in terms GDP per-capita growth than in terms of total GDP growth for the period 2008-13. Per-capita GDP growth was nevertheless higher in Sweden than in most other European countries, including the other Nordic countries (Erixon, 2015, p. 594).

Viewed from this alternative standpoint, the economic contribution of refugee migration to the host country's economy does not seem to be adequately captured by measuring the difference between refugees' tax payments and the costs of what they receive in terms of welfare benefits and services. This point has been also raised by Philippe Legrain (2016) who criticised the research design of studies focusing one-sidedly on the alleged fiscal costs of refugee migration. For example, Legrain observed that Ruist's aforementioned study assumed that public spending for certain public services (e.g., defence and infrastructure) was higher for refugees than for the rest of the Swedish population, without justifying this assumption. More importantly, Legrain argued that the fiscal accountability perspective used in this kind of studies tends to underestimate the positive externalities - what he calls "dividends" - associated with refugee reception. These dividends range from fuelling consumption demand in times of economic downturn to filling gaps in the labour market and reversing demographic ageing trends in receiving countries. He added that, in order to maximise the yield of these dividends, receiving countries should develop and maintain an adequate reception system and design integration policies that effectively enhance the refugees' potential contribution to their host societies.

In this respect, research has shown that granting permanent or temporary asylum has an influence on refugee prospects for social integration into the host societies (Dustmann, Fasani, Frattini, Minale, \& Schönberg, 2017). The acquisition of host country specific human capital (e.g., proficiency in the local language and other skills that are specific to the host country economy) is a costly investment that may not give returns in the coun- try of origin. Therefore, the returns for individual investments in human capital depend primarily on whether refugees are given a clear perspective concerning their future legal status in the host country, which in turn affects their likelihood to stay or re-emigrate.

European governments, including Sweden, have responded to the refugee crisis by setting in motion political initiatives moving in the opposite direction; i.e., restricting asylum policies, shifting from permanent to temporary residence permits and imposing limitations on family reunification. These initiatives are typically presented as responses to the receiving population's anxiety over rising immigration levels. In the case of Sweden, the U-turn in asylum policy has been interpreted as an attempt to counteract the political discourse of, and growing support for, the extreme right-wing party of the Swedish Democrats (Sverigedemokraterna in Swedish) (e.g., Demker \& Van der Meiden, 2016). According to the latest polls, this party would receive almost one fifth of the votes if elections were to be held as this text is written.

Another, and perhaps more tenable, explanation for this EU-wide policy development has recently been provided by Peo Hansen (2017a), referring to the financial constraints imposed by the EU's enduring austerity regime. According to Hansen, the governments of EU member states that decided for a rapid U-turn in their asylum policy in the face of the upsurge in refugees such as Sweden and Germany, did not fail to anticipate the latent resentment of their populations towards immigrants. Rather, they failed to anticipate the structural incompatibility between a refugee policy aimed at yielding long-term dividends and the EU-wide, short-sighted austerity regime which imposes the achievement of permanent budget surpluses to all member-states.

As explained in the next section, in the case of Sweden, the roots of this incompatibility between long-term social integration goals and short-term austerity requirements neither emerged during the refugee crisis, nor as a response to the Eurozone crisis that began at the end of 2009. They can instead be traced back to the second half of the 1990s when a series of policy changes led to a "workfarist" reorientation of the Swedish welfare state and the introduction of a new fiscal policy framework.

\section{Austerity-Based Migration Policy in the Swedish Consolidation State}

At the beginning of the 1990s, Sweden experienced a financial crisis that had a wide-ranging, negative impact on all sectors of the economy, as well as on society as a whole, resulting in the deepest recession and the highest level of unemployment in the post-war period (Erixon, 2015; Stenfors, 2016). That crisis and the policy responses to it are generally recognised as key factors that prompted, or at least accelerated, the retrenchment of the Swedish welfare state (e.g., Haffert \& Mehrtens, 2015; Streeck, 2017). 
In the mid-1990s, a newly installed social democratic government undertook severe austerity measures, introducing a new fiscal framework that institutionalised the prioritisation of balanced budgets and inflation control over full employment, thus signalling a "clear break" with the long-standing tradition of Keynesian-inspired policy which had been dominant in the country since the $1930 \mathrm{~s}$ (Erixon, 2015, p. 569).

The introduction of the new fiscal framework resulted in a radical transformation of the Swedish model. According to Wolfgang Streeck (2017, p. 151), Sweden ceased to be the forerunner of the social democratic welfare regime to emerge as "[t]he most advanced case of modern consolidation state with a firmly established austerity regime". The notion of "consolidation state" was proposed by Streeck (2014) as an antithesis to the Keynesian welfare state. It describes a political-economic regime characterised by a rigid adherence to austerity politics as a confidence-building strategy for retaining the trust of financial markets, and thus attracting financial investments for refinancing public debt. In addition, the consolidation state is typically based on a cross-party consensus on the idea that balanced budgets should be achieved primarily by reducing public expenditure rather than by raising taxes.

Since the introduction of the new fiscal framework in 1997, the Swedish government has been forced to run a budget surplus of one percent of GDP annually, and to hold public expenditure below a three-year rolling ceiling. The expenditure ceiling limits the room for expansionary economic and welfare policies, but does not affect revenues (Haffert \& Mehrtens, 2015, p. 137). This means that any budget surplus accrued through the year can be used for reducing the tax burden, but any tax cut financed by budget surpluses entails a corresponding drop in public expenditure.

A consequence of the more restrictive fiscal policy was the achievement of stable budget surpluses during the 1998-2007 period, with the sole exception of a small deficit in 2002 during the international downturn associated with the dot-com bubble burst (Erixon, 2015, p. 573). At the same time, Sweden experienced a 20percentage point decline in public expenditure between 1993 (the peak of the early-1990s crisis) and 2012, which was accompanied by a parallel and slower but sustained decline in public revenue by about ten percentage points (Haffert \& Mehrtens, 2015, p. 137). The achievement of the targeted budget surpluses was essentially ensured by a reduction in public expenditure that was faster than that of public revenue, resulting in across-the-board cuts affecting all areas of the welfare state.

The period after the early-1990s' crisis saw the lowering of compensation rates for all income support measures, as well as a reduction in their coverage. A report commissioned in 2012 by the Swedish parliament indicated that the Swedish model had lost its international primacy in terms of benefit generosity, concluding that its previously renowned high levels of income protection had to be considered "part of history" (Palme et al., 2012, p. 30). The resulting decrease in redistributive impact of the Swedish welfare state was a key driver of rising income inequality as shown by the increase in the poverty rate of non-employed individuals in receipt of welfare benefits (Jonsson, Mood, \& Bihagen, 2016).

Together with decreased benefit generosity and coverage, labour market policy was reorientated from an approach with a strong focus on training and upskilling the unemployed, to a more "workfarist" approach placing a stronger emphasis on job search advice and monitoring, including sanctions for non-compliance. A recent study found that although expenditure on active measures is still higher in Sweden than in other EU countries, the share of participants in training programmes declined to historically low levels after the 2007-08 crisis, while those in subsidised employment measures reached a historical high (Bengtsson, Porte, \& Jacobsson, 2017). The two types of activation policy differ in that subsidised employment measures are typically less costly than training programmes, but the latter tend to be more effective from a long-term perspective; e.g., with regard to the quality of the obtained employment and earnings levels. The shift in activation policy can thus be seen "as a response to a longer trajectory of running a budget surplus and of fiscal consolidation policies" (Bengtsson et al., 2017, p. 375).

The declining generosity of welfare benefits and the cost-reducing reform of labour market policy negatively affected the situation of foreign-born individuals in particular. Since the early-1990s, newly arrived immigrants, and especially those with refugee status or family reunification as the grounds for residence permits, have had lower employment rates and higher benefit dependence rates than the rest of the population (Åslund, Forslund, \& Liljeberg, 2017; Riksrevisionen, 2015).

As in other policy areas, asylum policy was also influenced by the general workfarist reorientation of the Swedish model. The refugee reception system was first reformed in 1994 by giving municipalities the power to offer newly-arrived asylum seekers the possibility of participating in non-mandatory introductory programmes, with the aim of assisting their socioeconomic integration through individually-tailored introduction plans. A major change occurred in December 2010 with the launch of the so-called "Establishment Reform" (also known as "Law on introduction activities for recently arrived immigrants", or in Swedish: Lag om etableringsinsatser för vissa nyanlända invandrare). The Establishment Reform did not affect the voluntary nature of introductory programmes. Yet, participants became entitled to a new benefit, the Establishment Allowance, which is more generous than the social assistance benefits received in the case of non-participation. In reality, the Establishment Reform indicated a shift towards a more duty-based and sanction-orientated approach. In fact, claims for social assistance can be rejected by the municipalities in cases of participation refusal in the programmes, and the Estab- 
lishment Allowance can be reduced, or even withdrawn, in cases of non-compliance to the individually-tailored plan (Borevi, 2017, p. 277). The main aim of the Establishment Reform was to centralise and standardise the implementation of such programmes by transferring the responsibilities for their design and administration from the municipalities to the state-controlled Public Employment Service (PES). Meanwhile, the PES was given the possibility of contracting out the actual implementation of the programmes to private actors, the so-called Establishment Pilots.

The decision to involve private actors in introductory programmes for refugees was in line with the New Public Management philosophy underpinning recent Swedish public sector reforms. Since the early-1990s, public sector agencies have been increasingly called on to adopt private sector practices and solutions in order to improve their performance as well as responsiveness to the demands of citizens who are treated as active consumers capable of making conscious and informed choices reflecting their preferences (Hartman, 2011). In this respect, "freedom of choice" was explicitly set out as a pivotal policy objective of the reform in the government proposition (Proposition 2009/10:60). Although newcomers are virtually allowed to choose their own Establishment Pilot, few of them are able to navigate the unfamiliar system, primarily due to language barriers. In this respect, the Establishment Reform has been described as inspired by a "neoliberal" notion of empowerment, expecting that newcomers should take responsibility for their own integration process, but without considering the structural barriers they face in Swedish society (Fernandes, 2015, p. 258).

Another criticised feature of the reform is the results-based remuneration system for the Establishment Pilots (Sibbmark, Söderström, \& Åslund, 2016). A "registration-premium" (startersättning in Swedish) encouraged the exchange of refugees among Establishment Pilots through their re-enrolling in new individuallytailored introductory programmes provided by other subcontractors. Furthermore, the achievement of shortterm employment goals became more important than that of longer-term social integration objectives because the Establishment Pilots can receive a "speed-premium" (snabbhetspremie in Swedish) upon rapid labour market integration of their "clients". Although the remunerationsystem implies compensation in the case of refugees' enrolment in higher education, in practice they cannot afford this option because of the high resettling and accommodation costs in university cities (Pelling \& Bender, 2017).

The U-turn in asylum policy at the end of 2015 created additional pressures on some newly arrived refugees to accelerate their entry into the Swedish labour market. With the suspension of the previous asylum policy, refugees who are not accepted under the EU-quota system receive a three-year temporary residence permit that can be converted into a permanent one only if they can prove that they are able to support themselves through paid work. This self-sufficiency requirement is pressuring refugees with temporary permits to take any job, regardless of their educational background and prior work expertise. They often enter the Swedish labour market without having their qualifications recognised, as the validation procedure can take several months, and even up to several years in the case of high-skilled individuals (Riksrevisionen, 2015, p. 119).

The visible effect of the aforementioned policy changes was a sudden increase in the share of refugees registering to PES just after arriving in the country, albeit there was no parallel improvement in the transition rate to stable employment (Åslund et al., 2017, p. 125). Sweden is still marked by one of the highest gaps in employment rates between immigrants and natives across OECD countries, even though the levels of labour market participation are comparatively high for both groups (Riksrevisionen, 2015, p. 40). Disaggregated data show that this gap is due to the fact that immigration to Sweden is dominated by refugees and their family members who often face great difficulties in entering the labour market.

At the same time, refugees who manage to find employment are disproportionately concentrated in the less favourable segments of the labour market and especially in less qualified employment positions. This means that the jobs refugees do are often not commensurate with their skills, educational qualifications and prior working experience in their country of origin. The latest OECD Migration Outlook shows that Sweden has the fourth highest rate of over-qualification among immigrants in the OECD, after those of Italy, Greece and Denmark (OECD, 2017, p. 68). Available data show that this problem especially concerns the recently arrived asylum seekers and refugees. According to OECD figures, the share of recent immigrants being more skilled or educated than is needed to do their job increased by ten percentage points between 2007-2008 and 2014-2015; i.e., from 30 to 40 percent of the total (OECD, 2017, p. 69).

\section{Conclusions}

Almost two years after the U-turn in asylum policy, the predictions about the risk of a possible "system breakdown", caused by the recent surge of refugee arrivals to Sweden, appear to be falsified by the exceptionally positive trend in local government finance. The latest estimates from the Swedish Association of Local Authorities and Regions indicate that the various measures targeted at refugees had the secondary effect of providing a positive fiscal stimulus to economic growth at the local level; all the more unexpected according to the dominant political narrative of "system breakdown". In fact, 2016 was a record year for Swedish local governments in terms of aggregate budget surplus; the largest ever recorded in the 21st century (SKL, 2017a, p. 35). This budget surplus was about 25 billion Swedish kronor (about 2.5 billion Euros) in 2016, compared to 9.7 billion kronor (about 970 mil- 
lion Euros) in 2015, and the increase was exclusively due to the extent of state support to municipalities receiving asylum seekers and refugees.

Small municipalities, and in particular the rural ones suffering from long-term demographic and economic decline, are those that have benefited the most in terms of central government's per capita contribution (SKL, 2017a, p. 40). It is no surprise then, that what had been anticipated to be a burden at the national level came to be often represented as an opportunity for economic growth at the municipal level. Refugee intake came to often be seen under a positive light by the local councillors of municipalities which benefitted the most from central government's support, regardless of their party affiliation (Hansen, 2017b). In these municipalities, refugee migration contributed directly to a reversal of population decline, the increase in the number of school pupils in schools that had been threatened with closure, as well as a major boost in local consumption, thereby generating further employment opportunities and revenue streams for the local population.

Yet, central government's support to refugeereceiving municipalities is only temporary, and existing measures will gradually be phased out before the longlasting and stable integration of refugees into the local communities can create self-sustaining positive effects. The phasing out of government support to municipalities is the consequence of the more restrictive asylum policy, which has also resulted in a general decline in refugee acceptance rates. In the present situation, local authorities are urged to find alternative financial sources to keep their budgets balanced; a requirement that they are legally bound to meet under the national financial framework (SKL, 2017b).

An alternative strategy could have been to embark on a more ambitious growth agenda based on "refugee Keynesianism" (Hansen, 2017a) by investing in policy measures that enable refugees to maximise their human capital, thus helping them to secure employment opportunities commensurate with their skills and approaching greater equality with natives. This would be a strategy requiring considerable short- and medium-term public investments, but yielding long-term beneficial dividends. As discussed in previous pages, this strategy does not seem to be compatible with the financial constraints imposed by the institutional machinery of the Swedish "consolidation state" (Streeck, 2014).

As we write these concluding remarks, there is an emerging disagreement between the two main political blocs concerning the issue of changing labour market entry conditions for refugees in order to enhance their employment possibilities. For the conservative party, this would imply lowering entry-level wages in order to stimulate the creation of low-skilled jobs explicitly targeted at refugees. The Social Democratic Prime Minister Stefan Löfven criticised the conservatives' proposal for risking driving down wages across the labour market. At the same time, however, he argued that the Swedish labour market should not be adapted to the needs of recently arrived refugees, but rather the latter should adapt themselves to the high-skill needs of the Swedish labour market (Olsson \& Tedesjö, 2017).

The question remains about the role the Swedish welfare state should play in the "adaptation" process of refugees. The current policy inherited by the previous right-wing government has proven to be ineffective, and in some circumstances may have facilitated exploitative labour conditions for refugees, especially those with temporary permits. Apparently, the alternative policy advocated by the current red-green government would seek to combine lower entry-level wages with new skill-enhancement and training measures in order to match refugees with existing job vacancies in the Swedish labour market. But will this policy be feasible under the constraints dictated by the austerity regime of the Swedish consolidation state? We leave this question open, pending future political developments until the next Swedish general elections in September 2018.

\section{Acknowledgements}

The article benefited from insightful suggestions by Peo Hansen. However, the authors are alone responsible for eventual errors, omissions and opinions expressed in the article.

\section{Conflict of Interests}

The authors declare no conflict of interests.

\section{References}

Aldén, L., \& Hammarstedt, M. (2016). Refugee immigration and public sector finances: Longitudinal evidence from Sweden (Working Paper 2016:8). Växjö: Centre for Labour Market and Discrimination Studies, Linnaeus University, Sweden.

Alesina, A., \& Glaeser, E. L. (2004). Fighting poverty in the US and Europe: A world of difference. Oxford: Oxford University Press.

Åslund, O., Forslund, A., \& Liljeberg, L. (2017). Labour market entry of non-labour migrants-Swedish evidence. In A. P. Damm \& O. Åslund (Eds.), Nordic economic policy review (pp. 115-158). Copenhagen: Nordic Council of Ministers.

Bengtsson, M., Porte, C., \& Jacobsson, K. (2017). Labour market policy under conditions of permanent austerity: Any sign of social investment? Social Policy \& Administration, 51(2), 367-388.

Borevi, K. (2017). Diversity and solidarity in Denmark and Sweden. In K. Banting \& W. Kymlicka (Eds.), Strains of commitment: The political sources of solidarity in diverse societies (pp. 364-388). Oxford: Oxford University Press.

Dahlstedt, M., \& Neergaard, A. (2016). Crisis of solidarity? Changing welfare and migration regimes in 
Sweden. Critical Sociology. https://doi.org/10.1177/ 0896920516675204

Demker, M., \& Van der Meiden, S. (2016). Allt starkare polarisering och allt lägre flyktingmotstånd. In J. Ohlsson, H. Oscarsson, \& M. Solevid M. (Eds.), Ekvilibrium (pp. 197-214). Gothenburg: SOM-institutet, Gothenburg University.

Dustmann, C., Fasani, F., Frattini, T., Minale, L., \& Schönberg, U. (2017). On the economics and politics of refugee migration. Economic Policy, 32(91), 497-550.

Erixon, L. (2015). Can fiscal austerity be expansionary in present-day Europe? The lessons from Sweden. Review of Keynesian Economics, 3(4), 567-601.

Fernandes, A. G. (2015). (Dis)Empowering new immigrants and refugees through their participation in introduction programs in Sweden, Denmark, and Norway. Journal of Immigrant \& Refugee Studies, 13(3), 245-264.

Haffert, L., \& Mehrtens, P. (2015). From austerity to expansion? Consolidation, budget surpluses, and the decline of fiscal capacity. Politics \& Society, 43(1), 119-148.

Hansen, P. (2017a). Asylum or austerity? The 'refugee crisis' and the Keynesian interlude. European Political Science, 1-12.

Hansen, P. (2017b). Flyktingarna orsaken till god ekonomi. ETC. Retrieved from https://www.etc.se/ ekonomi/flyktingarna-orsaken-till-god-ekonomi

Hartman, L. (2011). Konkurrensens konsekvenser-vad händer med svensk välfärd. Stockholm: SNS förlag.

Jonsson, J. O., Mood, C., \& Bihagen, E. (2016). Poverty trends during two recessions and two recoveries: Lessons from Sweden 1991-2013. IZA Journal of European Labor Studies, 5(3).

Kasparek, B., \& Speer, M. (2015). Of hope. Hungary and the long summer of migration. Retrieved from: http://bordermonitoring.eu/ungarn/2015/09/of-hope -en

Kymlicka, W., \& Banting, K. G. (2006). Immigration, multiculturalism, and the welfare state. Ethics \& International Affairs, 20(3), 281-304.

Legrain, P. (2016). Refugees work: A humanitarian investment that yields economic dividends. New York: Tent Foundation.

Mau, S., \& Burkhardt, C. (2009). Migration and welfare state solidarity in Western Europe. Journal of European Social Policy, 19(3), 213-229.

Norocel, O. C. (2016). Populist radical right protectors of the folkhem: Welfare chauvinism in Sweden. Critical Social Policy, 36(3), 371-390.

OECD. (2011). Divided we stand: Why inequality keeps rising. Paris: OECD publishing.

OECD. (2017). International migration outlook 2017. Paris: OECD publishing.

Olsson, H., \& Tedesjö, E. (2017) Löfven: hårdare tag krävs mot våldet och gängkriminaliteten. $D a$ gens Nyheter. Retrieved from https://www.dn.se/ arkiv/nyheter/lofven-hardare-tag-kravs-mot-valdetoch-gangkriminaliteten
Palme, J., Ferrarini, T., Sjöberg, O., \& Nelson, K. (2012). Sveriges socialförsäkringar i jämförande perspektiv En institutionell analys av sjuk-, arbetsskade-och arbetslöshetsförsäkringarna i 18 OECD-länder 1930 till 2010. Stockholm: Statens Offentliga Utredningar.

Pelling, L., \& Bender, G. (2017). Nyanlända behöver utbildning-inte politikernas låglönejobb. Dagens Nyheter. Retrieved from https://www.dn.se/debatt/ nyanlanda-behover-utbildning-inte-politikernas-lag lonejobb

Proposition 2009/10:60. Nyanlända invandrares arbetsmarknadsetablering-egenansvar med professionellt stöd. Retrieved from http://www.regeringen. $\mathrm{se} / \mathrm{sb} / \mathrm{d} / 8115 / \mathrm{a} / 135998$

Riksrevisionen. (2015). Nyanländas etablering: $\ddot{A} r$ statens insatser effektiva? Stockholm: Swedish National Audit Office.

Rosén, H. (2014). Reinfeldt: öppna era hjärtan för de utsatta. Dagens Nyheter. Retrieved from https://www. dn.se/nyheter/politik/reinfeldt-oppna-era-hjartanfor-de-utsatta

Rothstein, B. (2017). Immigration and economic growth: is Keynes back? Social Europe. Retrieved from https://www.socialeurope.eu/immigration-and-eco nomic-growth-is-keynes-back

Ruist, J. (2015). The fiscal cost of refugee immigration: The example of Sweden. Population and Development Review, 41(4), 567-581.

Rydgren, J., \& Van der Meiden, S. (2016). Sweden, now a country like all the others? The radical right and the end of Swedish exceptionalism. Stockholm: Department of Sociology, Stockholm University.

Schierup, C.-U., \& Ålund, A. (2011). The end of Swedish exceptionalism? Citizenship, neoliberalism and the politics of exclusion. Race \& Class, 53(1), 45-64.

Sibbmark, K., Söderström, M., \& Åslund, O. (2016). Marknadsmekanismer $i$ teori och praktik-erfarenheter från etableringslotsarna (IFAU Rapport 2016:19). Uppsala: IFAU.

SKL. (2017a). Ekonomirapporten, maj 2017-om kommunernas och landstingens ekonomi. Stockholm: Sveriges Kommuner och Landsting.

SKL. (2017b). Ekonomirapporten, oktober 2017-om kommunernas och landstingens ekonomi. Stockholm: Sveriges Kommuner och Landsting.

Stenberg, E. (2015). Margot Wallström om bränderna: SD har ett ansvar. Dagens Nyheter. Retrieved from https://www.dn.se/nyheter/sverige/margotwallstrom-om-branderna-sd-har-ett-ansvar

Stenfors, A. (2016). Swedish financialisation: 'Nordic noir' or 'safe haven'? In E. Hein, D. Detzer, \& N. Dodig (Eds.), Financialisation and the financial and economic crises: Country studies (pp. 192-213). Cheltenham: Edward Elgar.

Streeck, W. (2014). Buying time: The delayed crisis of democratic capitalism. New York: Verso Books.

Streeck, W. (2017). A new regime: The consolidation state. In D. King \& P. Le Galès (Eds.), Reconfiguring 
European states in crisis (pp. 139-157). Oxford: Oxford University Press.

Svallfors, S., \& Tyllström, A. (2018). Resilient privatization: The puzzling case of for-profit welfare providers in Sweden. Socio-Economic Review. https://doi.org/
$10.1093 / \mathrm{ser} / \mathrm{mwy} 005$

Taylor-Gooby, P. (2005). Is the future American? Or, can left politics preserve European welfare states from erosion through growing 'racial' diversity? Journal of Social Policy, 34(4), 661-672.

\section{About the Authors}

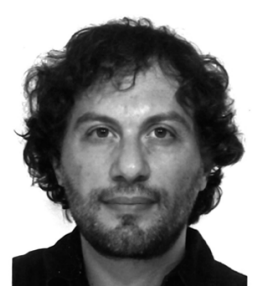

Simone Scarpa is a Senior Lecturer at the Institute for Research on Migration, Ethnicity and Society (REMESO), Linköping University. He has a disciplinary background in Sociology, Urban Studies and Social Work. His research interests cover topics related to socio-spatial polarization in cities, welfare state restructuring and decentralization, migration policy, poverty and inequality analysis.

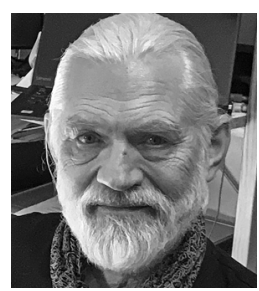

Carl-Ulrik Schierup is a Professor at the Institute for Research on Migration, Ethnicity and Society (REMESO), Linköping University. He has a disciplinary background in Social Anthropology and Sociology. He has published widely on issues of international migration and ethnic relations, globalization, nationalism, multiculturalism, citizenship, working-life and labour relations. 